\title{
Elementy niezawodności stalowych spawanych zbiorników na ciecze i gazy płynne
}

\author{
Elements of the structural reliability \\ of steel welded tanks liquids and gases in liquid
}

\section{Streszczenie}

W artykule przedstawiono ogólne zasady zarządzania niezawodnością stalowych spawanych zbiorników na ciecze wg eurokodów EN 1990 i EN 1993-4-2 oraz podano podstawy ich obliczeń i wymiarowania w stanie zniszczenia plastycznego ze szczególnym uwzględnieniem imperfekcji montażowych i spawalniczych. Przeprowadzono weryfikację współczynników nośności plastycznej krajowych wyrobów hutniczych wyprodukowanych w latach 1963-1968 oraz 1976-1980. Sposób wykorzystania procedur normowych w stanie plastycznym zilustrowano przykładem liczbowym obliczeń statycznych i wymiarowania powłoki stalowego zbiornika stokażowego przeznaczonego do magazynowania wody amoniakalnej.

\section{Wstęp}

Przedstawiono analizę niezawodności spawanych stalowych naziemnych zbiorników walcowych na ciecze i gazy płynne, dotyczy konstrukcji projektowanych wg reguł i zasad eurokodu PN-EN 1993-4-2 [1]. Są to zbiorniki, które spełniają następujące warunki:

1. Charakterystyczne ciśnienie wewnętrzne w przestrzeni powietrzno-gazowej jest nie mniejsze niż $-100 \mathrm{mbar}(-10,0 \mathrm{kPa})$ i nie większe niż $500 \mathrm{mbar}$ $(50,0 \mathrm{kPa})$.

2. Obliczeniowa temperatura powłoki zbiornika zawiera się w przedziale od $-50^{\circ} \mathrm{C}$ do $+300^{\circ} \mathrm{C}$, a dla zbiorników wykonanych ze stali odpornych na korozję (wg PN-EN 10028 [2]) przedział dopuszczalnej temperatury wynosi $-165 \div 300^{\circ} \mathrm{C}$.

Prof. dr hab. inż. Marian Gwóźdź, dr inż. Tomasz Michałowski - Politechnika Krakowska.

\section{Abstract}

The paper presents general rules for the management of structural reliability of weld steel tanks for liquids according to Eurocodes EN 1990 and EN 1993-4-2. Basis of design in plastic limit state, including assembly and weIding imperfections, are presented too. Verification of the national partial safety factor for plastic limit state of steel products produced in the years 1963-1968 and 19761980 was achievied. Calculations of steel tank for ammonia water are example of design of structures in plastic limit state according to Eurocode rules.
3. Maksymalny obliczeniowy poziom składowanej cieczy zawiera się w przestrzeni walcowej zbiornika (nie jest zapełniana przestrzeń stożkowa pod dachem zbiornika).

4. Wytwarzanie i montaż zbiorników podlegają wymaganiom norm EN 14015 [3], EN 14620 [4] oraz EN 1090 [5].

Wskazany zakres dopuszczalnego ciśnienia w przestrzeni powietrzno-gazowej zbiorników jest zbieżny z wymaganiami krajowymi sformułowanymi w Rozporządzeniu Ministra Gospodarki dla zbiorników bezciśnieniowych i niskociśnieniowych podlegających dozorowi Urzędu Dozoru Technicznego [6].

Inny podział zbiorników, przyjęty w eurokodzie PN-EN 1993-4-2, wiąże się z klasą konsekwencji (wg klasyfikacji przyjętej w PN-EN 1990 [7] jak poniżej): 1. Klasa konsekwencji CC3, która obejmuje zbiorniki o dowolnej pojemności na ciecze i gazy płynne toksyczne lub wybuchowe oraz zbiorniki o dużej pojemności na ciecze palne lub szkodliwe dla środowiska wodnego w terenie zabudowanym. 
2. Klasa konsekwencji CC2, która obejmuje zbiorniki o średniej pojemności na ciecze palne lub szkodliwe dla środowiska wodnego $w$ terenie zabudowanym.

3. Klasa konsekwencji CC1, która obejmuje zbiorniki dla rolnictwa oraz zbiorniki na wodę.

W artykule przedstawiono ogólne zasady zarządzania niezawodnością stalowych zbiorników na ciecze oraz podano podstawy ich obliczeń i wymiarowania w stanie zniszczenia plastycznego ze szczególnym uwzględnieniem imperfekcji montażowych i spawalniczych. Sposób wykorzystania procedur normowych w stanie plastycznym zilustrowano przykładem liczbowym obliczeń statycznych i wymiarowania powłoki stalowego zbiornika stokażowego przeznaczonego do magazynowania wody amoniakalnej.

\section{Elementy niezawodności zbiorników stalowych}

W celu zróżnicowania niezawodności konstrukcji budowlanych PN-EN 1990 [7] definiuje klasy konsekwencji zniszczenia CC (wg opisu zamieszczonego w tablicy B1 normy). Klasy konsekwencji CC są powiązane z klasami niezawodności konstrukcji RC w ten sposób, że klasie konsekwencji CC3 odpowiada klasa niezawodności RC3, klasie CC2 - RC2 oraz klasie CC1 - RC1. Klasy niezawodności konstrukcji RC w stanie granicznym nośności są zdefiniowane w tablicy I (wg [7]), w zależności od zalecanej minimalnej wartości wskaźnika niezawodności $\beta_{u}$ w okresie odniesienia $\mathrm{t}=1$ rok albo $\mathrm{t}=50$ lat.

Wskaźnik niezawodności $\beta$ jest pojęciem znanym w teorii niezawodności konstrukcji budowlanych (por. np. [10]) w metodzie obliczeń probabilistycznych poziomu 2 - FORM (First Order Reliability Method). Wskaźnik $\beta$ jest miarą niezawodności, którą można wyspecyfikować w badaniach statystycznych losowych obciążeń i losowej nośności konstrukcji budowlanych. Kryterium niezawodności konstrukcji budowlanych w metodzie probabilistycznej poziomu 2 o postaci:

$$
\beta \geq \beta_{u}
$$

w przypadku podstawowym można zastąpić porównaniem wartości obliczeniowych: nośności $R_{d}$ i odpowiadającego jej efektu obciążeń $E_{d}$. W zaleceniach PN-EN 1990 dotyczących podstaw projektowania

Tablica I. Zalecane wartości wskaźnika niezawodności $\beta$ w stanie granicznym nośności wg PN-EN 1990 [7]

Table I. Recommended values of factor for structural reliability $\beta$ in the plastic limit state acc. to PN-EN 1990 [7]

\begin{tabular}{|c|c|c|}
\hline \multirow{2}{*}{$\begin{array}{c}\text { Klasa } \\
\text { niezawodności }\end{array}$} & \multicolumn{2}{|c|}{ Minimalne wartości $\beta_{u}$} \\
\cline { 2 - 3 } & okres odniesienia 1 rok & okres odniesienia 50 lat \\
\hline RC3 & 5,2 & 4,3 \\
\hline RC2 & 4,7 & 3,8 \\
\hline RC1 & 4,2 & 3,3 \\
\hline
\end{tabular}

konstrukcji rozpatruje się przypadek, w którym warunek stanu granicznego można wyrazić za pomocą skalarowej, jednoparametrowej nośności R i stowarzyszonego z nią efektu oddziaływań E w postaci:

$$
\begin{gathered}
E_{d}=E\left\{F_{d 1}, F_{d 2}, \ldots a_{d 1}, a_{d 2}, \ldots \theta_{d 1}, \theta_{d 2}\right\} \leq R_{d} \\
R_{d}=R\left\{X_{d 1}, X_{d 2}, \ldots a_{d 1}, a_{d 2}, \ldots \theta_{d 1}, \theta_{d 2}\right\}
\end{gathered}
$$

gdzie: indeks „d" oznacza wartości obliczeniowe: $F_{d 1}, F_{d 2}, \ldots$ - oddziaływań na konstrukcję, $\mathrm{X}_{\mathrm{d} 1}, \mathrm{X}_{\mathrm{d} 2}, \ldots$ - właściwości mechanicznych materiału konstrukcji, $a_{\mathrm{d} 1}, a_{\mathrm{d} 2}, \ldots-$ właściwości geometrycznych konstrukcji, $\theta_{\mathrm{d} 1}, \theta_{\mathrm{d} 2} \ldots$ - parametrów niepewności modelu obliczeniowego.

W eurokodach przyjęto konwencję sprawdzania niezawodności, wg której wartości obliczeniowe $x_{d}$ zwykle nie są podstawiane bezpośrednio do równania stanu granicznego, lecz są podstawiane tzw. wartości reprezentatywne $X_{\text {rep }}$ i $F_{\text {rep}}$, którymi mogą być:

- wartości charakterystyczne, czyli kwantyle dla: obciążeń $-F_{k}$, wytrzymałości materiału $-n X_{k}$ i cech geometrycznych $-a_{d}$ (gdzie $\eta$ - współczynnik konwersji),

- wartości nominalne (wartości centralne cech geometrycznych $a_{\text {nom }}$ ).

Wartości obliczeniowe $F_{d}$ i $X_{d}$ otrzymuje się w takim razie, mnożąc lub dzieląc wartości reprezentatywne przez odpowiednie współczynniki częściowe:

$$
\begin{aligned}
& F_{d}=F_{r e p} \gamma_{F} \rightarrow E_{d}=E\left(F_{k \gamma P} a_{d}\right) \\
& X_{d}=\eta X_{K} / \gamma_{M} \rightarrow R_{d}=R\left(\eta X_{K} / \gamma_{M}, a_{d}\right)
\end{aligned}
$$

Współczynniki częściowe $-\gamma_{F}$ we wzorze (3) i $\gamma_{M}$ we wzorze (4) - uwzględniają losową zmienność oddziaływań, wytrzymałości materiału oraz błąd modelowania tych zmiennych losowych i można je zapisać w postaci iloczynów:

$$
\gamma_{F}=\gamma_{f} \gamma_{S d^{\prime}}, \gamma_{M}=\gamma_{m} \gamma_{R d}
$$

Wartości liczbowe współczynników obciążenia $\gamma_{F}$ wyspecyfikowane w eurokodzie EN 1990 zostały zredagowane w postaci trzech zestawów, w zależności od analizowanego przypadku stanu granicznego [7]. Są

Tablica II. Zalecane wartości współczynników częściowych $\gamma_{F}$ do oddziaływań na zbiorniki stalowe wg PN-EN 1993-4-2 [1]

Table II. Recommended values of partial factors $\gamma_{F}$ to interaction on steel tanks acc. to PN-EN 1993-4-2 [1]

\begin{tabular}{|c|c|c|c|}
\hline \multirow{2}{*}{$\begin{array}{c}\text { Sytuacja } \\
\text { obliczeniowa }\end{array}$} & Rodzaj cieczy & $\begin{array}{c}\gamma_{F} \text { do oddzia- } \\
\text { ływań zmien- } \\
\text { nych od cieczy }\end{array}$ & $\begin{array}{c}\gamma_{F} \text { do od- } \\
\text { działywań } \\
\text { stałych }\end{array}$ \\
\hline \multirow{2}{*}{$\begin{array}{c}\text { Obciążenia od } \\
\text { cieczy podczas } \\
\text { eksploatacji }\end{array}$} & $\begin{array}{c}\text { ciecze toksyczne } \\
\text { lub wybuchowe }\end{array}$ & 1,40 & 1,35 \\
\cline { 2 - 4 } & ciecze palne & 1,30 & 1,35 \\
\cline { 2 - 4 } & inne ciecze & 1,20 & 1,35 \\
\hline Próba wodna & wszelkie ciecze & 1,00 & 1,35 \\
\hline Oddziaływania & wszelkie ciecze & 1,00 & - \\
wyjątkowe & n & & \\
\hline
\end{tabular}


Tablica III. Miary niezawodności wytrzymałości stali wyznaczone w próbach statystycznych krajowych wyrobów hutniczych z lat $1963-1968$ wg [9] i 1976-1980 wg [10]

Table III. Values of reliability of steel strength achieved in static tests of steel products produced in the years 1963-1968 acc. to [9] and 19761980 acc. to [10]

\begin{tabular}{|c|c|c|c|c|c|c|c|c|c|c|}
\hline \multirow{2}{*}{ Znak stali } & \multicolumn{5}{|c|}{ Granica plastyczności $\mathrm{R}_{\mathrm{e}}, \mathrm{MPa}$} & \multicolumn{5}{|c|}{ Wytrzymałość na rozciąganie $R_{m}, M P a$} \\
\hline & $\bar{R}_{e}$ & $v_{R e}$ & $\beta_{R}$ & $\beta$ & $\gamma_{\text {Mo }}$ & $\bar{R}_{e}$ & $v_{R m}$ & $\beta_{R}$ & $\beta$ & $\gamma_{M 2}$ \\
\hline (1) & $(2)$ & (3) & (4) & $(5)$ & (6) & $(7)$ & (8) & (9) & $(10)$ & $(11)$ \\
\hline \multicolumn{11}{|c|}{ Próba statystyczna wytrzymałości blach wyprodukowanych w latach 1963-1968 } \\
\hline \multirow{2}{*}{$\begin{array}{c}\text { St3S } \\
\text { St3SX/Y }\end{array}$} & 304 & 0,081 & 2,80 & 3,50 & 1,03 & 447 & \multirow{2}{*}{0,066} & \multirow{2}{*}{2,53} & \multirow{2}{*}{3,16} & \multirow{2}{*}{1,04} \\
\hline & 294 & 0,100 & 2,69 & 3,36 & 1,05 & 447 & & & & \\
\hline $18 \mathrm{G} 2$ & 392 & 0,075 & 1,33 & 1,67 & 1,17 & 554 & \multirow{3}{*}{0,058} & \multirow{3}{*}{1,38} & \multirow{3}{*}{1,73} & \multirow{3}{*}{1,12} \\
\hline $18 G 2 A$ & 384 & 0,071 & 1,87 & 2,34 & 1,11 & 554 & & & & \\
\hline 18G2ACu & 372 & 0,066 & 2,38 & 2,64 & 1,06 & 554 & & & & \\
\hline \multicolumn{11}{|c|}{ Próba statystyczna wytrzymałości blach i kształtowników wyprodukowanych w latach 1976-1980 } \\
\hline \multirow{2}{*}{ Znak stali } & \multicolumn{5}{|c|}{ Granica plastyczności blach $R_{e}, \mathrm{MPa}$} & \multicolumn{5}{|c|}{ Granica plastyczności kształtowników $R_{e}, \mathrm{MPa}$} \\
\hline & $\overline{R_{e}}$ & $v_{R e}$ & $\beta_{R}$ & $\beta$ & $\gamma_{\text {Mo }}$ & $\bar{R}_{e}$ & $v_{R e}$ & $\beta_{R}$ & $\beta$ & $\gamma_{\text {Mo }}$ \\
\hline St0 & 291 & 0,113 & 2,89 & 3,61 & 1,026 & 280 & 0,113 & 2,65 & 3,32 & 1,065 \\
\hline \multirow{3}{*}{ St3SX/Y } & 299 & \multirow{3}{*}{0,077} & 2,78 & 3,48 & 1,026 & 287 & \multirow{3}{*}{0,077} & 2,35 & 2,94 & 1,068 \\
\hline & 291 & & 2,50 & 3,12 & 1,054 & 281 & & 2,13 & 2,66 & 1,093 \\
\hline & 280 & & 2,55 & 3,19 & 1,051 & 268 & & 2,08 & 2,60 & 1,098 \\
\hline \multirow{3}{*}{ St3S } & 308 & \multirow{3}{*}{0,068} & 3,48 & 4,36 & 1,000 & 296 & \multirow{3}{*}{0,068} & 3,03 & 3,79 & 1,000 \\
\hline & 300 & & 3,19 & 3,98 & 1,000 & 290 & & 2,79 & 3.49 & 1,022 \\
\hline & 288 & & 3,22 & 4,02 & 1,000 & 276 & & 2,72 & 3,40 & 1,027 \\
\hline \multirow{3}{*}{$\begin{array}{l}\text { St4 } \\
\text { St4S }\end{array}$} & 329 & \multirow{3}{*}{0,083} & 2,71 & 3,38 & 1,037 & 316 & \multirow{3}{*}{0,083} & 2,33 & 2,91 & 1,081 \\
\hline & 320 & & 2,45 & 3,06 & 1,067 & 309 & & 2,11 & 2,63 & 1,104 \\
\hline & 308 & & 2,46 & 3,08 & 1,065 & 295 & & 2,04 & 2,55 & 1,109 \\
\hline \multirow{3}{*}{$\begin{array}{c}18 G 2 \\
18 G 2 A\end{array}$} & 409 & \multirow{3}{*}{0,077} & 1,78 & 2,22 & 1,128 & 406 & \multirow{3}{*}{0,077} & 1,70 & 2,12 & 1,135 \\
\hline & 402 & & 1,58 & 1,98 & 1,146 & 400 & & 1,53 & 1,91 & 1,154 \\
\hline & 391 & & 1,93 & 2,41 & 1,114 & 386 & & 1,78 & 2,23 & 1,125 \\
\hline
\end{tabular}

to specyfikacje bezpieczne dla praktycznie wszystkich obiektów liniowych i kubaturowych (także zbiorników). Współczynniki częściowe $\gamma_{F}$ do oddziaływań na zbiorniki zostały jednak dodatkowo wyspecyfikowane w PN-EN 1993-4-2 (por. tabl. II) jako alternatywa względem rekomendacji zamieszczonej w eurokodzie PN-EN 1990.

Współczynniki nośności $\gamma_{M i}$ zostały wyspecyfikowane w [1] (rekomendacja CEN - Comité Européen de Normalisation) i przyjmują następujące wartości:

- $\gamma_{M 0}=1,00-$ nośność przekroju ścianki ze względu na uplastycznienie,

- $\gamma_{M 1}=1,10-$ nośność ścianki na wyboczenie,

- $\gamma_{M 2}=1,25$ - nośność przekroju ścianki na rozerwanie,

- $\gamma_{M 4}=1,00$ - nośność ścianki ze względu na nieprzystosowanie plastyczne,

- $\gamma_{M 5}=1,25$ - nośność połączeń, złączy spawanych lub śrubowych,

- $\gamma_{M 6}=1,10-$ nośność ścianki na zmęczenie.

Współczynniki częściowe $\gamma_{M i}$ mogą (i powinny) być określone w Załączniku krajowym. Wymaga to jednak dostępu do wiarygodnych danych statystycznych, co najmniej w zakresie niejednorodności wytrzymałości krajowych wyrobów hutniczych (współczynniki $\gamma_{M O}, \gamma_{M 2}, \gamma_{M 4} i \gamma_{M 6}$ ) oraz wytrzymałości złączy spawanych realizowanych w krajowych wytwórniach konstrukcji stalowych (współczynnik $\gamma_{M 5}$ ). Przykład weryfikacji współczynników $\gamma_{M 0}$ i $\gamma_{M 2}$ przedstawiono $w$ tablicy III, wykorzystując wyniki badań statystycznych wytrzymałości stali konstrukcyjnej z lat 1963-1968 opisane w [9] oraz późniejszych badań statystycznych z lat 1976-1978 opisanych w [10]. W tablicy III przytoczono wg [8] obliczone $w$ badaniach własnych miary niezawodności: współczynniki częściowe $\gamma_{M 0} \mathrm{i} \gamma_{M 2}$ (por. kolumny (6) i (11)) oraz częściowe wskaźniki niezawodności $\beta_{R}$ (por. kolumny (4) i (9), a także w kolumnach (5) i (10) odpowiadające im wskaźniki niezawodności "globalne" $\beta$ (w kolumnach (4) i (9) zgodnie z zapisem z PN-EN 1990 przyjęto: $\beta_{R}=0,8 \beta$ ).

Zestawione $w$ kolumnie (5) wartości wskaźnika niezawodności $\beta \geq 3,8$ spełniają wymagania klasy niezawodności RC2 (por. tabl. B2 z PN-EN 1990) tylko dla blach dowolnej grubości wyprodukowanych w latach 1970. ze stali St3S. Wyroby hutnicze, wykonane ze stali niskostopowych nie spełniają nawet wymagań najniższej klasy niezawodności RC1 $(\beta \geq 3,3)$. Taki sam wniosek wynika z porównania wartości współczynnika nośności przekroju $\gamma_{M 0}$. Pozytywnie natomiast wypadła weryfikacja współczynnika nośności na rozerwanie blach $\gamma_{M 2}$.

Zbiorniki stalowe należy projektować, różnicując wymagania niezawodności. Najprostszy sposób różnicowania niezawodności polega na redukcji współczynników obciążenia $\gamma_{F}$ współczynnikami redukcyjnymi $K_{F i}$. Są to mnożniki wyspecyfikowane w tablicy B3 zamieszczonej w normie PN-EN 1990 [4] i przytoczone w tablicy IV. Analogiczne współczynniki korekcyjne $K_{R i}$ mogą być użyte do redukcji współczynników częściowych nośności przekrojów i prętów $\gamma_{M i}$. W aktualnej edycji eurokodów współczynniki $K_{R i}$ nie zostały wyspecyfikowane. Przyjmując dla klasy niezawodności RC1 wartość 
Tablica IV. Wartości współczynników $\mathrm{K}_{\mathrm{Fi}}$ do oddziaływań wg [7] oraz wartości współczynników $\mathrm{K}_{\mathrm{Ri}}$ do nośności wg badań własnych

Table IV. KFi factor values to interactions acc. to [7] and $\mathrm{K}_{\mathrm{Ri}}$ factor values to loads acc. to own tests

\begin{tabular}{|c|c|c|c|c|}
\hline \multirow{2}{*}{ Współczynnik redukcyjny } & \multicolumn{3}{|c|}{ Klasa niezawodności zbiornika } \\
\cline { 3 - 5 } & $\mathrm{K}_{\mathrm{Fi}}$ & $\mathrm{RC} 1$ & $\mathrm{RC} 2$ & $\mathrm{RC}$ \\
\hline \multirow{3}{*}{} & $\mathrm{v}_{\mathrm{R}}$ & 0,90 & 1,00 & 1,10 \\
\cline { 2 - 5 } & 0,05 & $\mathrm{RC} 1$ & $\mathrm{RC} 2$ & $\mathrm{RC} 3$ \\
\cline { 2 - 5 } $\mathrm{K}_{\mathrm{Ri}}$ & 0,06 & 0,98 & 1,00 & 1,02 \\
\cline { 2 - 5 } & 0,07 & 0,97 & 1,00 & 1,03 \\
\cline { 2 - 5 } & 0,08 & 0,96 & 1,00 & 1,04 \\
\cline { 2 - 5 } & 0,09 & 0,95 & 1,00 & 1,04 \\
\cline { 2 - 5 } & 0,10 & 0,95 & 1,00 & 1,06 \\
\hline
\end{tabular}

wskaźnika niezawodności częściowego wg normy PNEN 1990: $\beta_{R}=0,8 \times 3,3=2,64$ oraz dla klasy niezawodności RC3 wartość $\beta_{R}=0,8 \times 4,3=3,44-$ w tablicy IV zestawiono przykładowe wartości współczynników korekcyjnych $\mathrm{K}_{\mathrm{Ri}}$ obliczone ze wzoru:

$$
K_{R i}=\frac{1-3,04 \mathrm{v}_{\mathrm{R}}}{1-\beta_{\mathrm{R}} \mathrm{v}_{\mathrm{R}}}
$$

dla różnych wartości współczynników zmienności granicy plastyczności $v_{R}$ krajowych stali konstrukcyjnych, otrzymanych $\mathrm{w}$ badaniach statystycznych (por. np. tabl. III).

\section{Podstawy obliczeń i wymiarowania}

Powłoki zbiorników modeluje się zgodnie z wymaganiami sformułowanymi w eurokodzie PN-EN 19931-6:2007 [11], które są spełnione, jeśli w modelu numerycznym powłoki uwzględni się wszystkie elementy usztywniające, otwory oraz przyłącza. Ponadto rozwiązania konstrukcyjne zbiornika powinny odzwierciedlać przyjęte $w$ analizie statycznej warunki brzegowe. Metody analizy statycznej są powiązane z klasą konsekwencji zbiornika. W szczególności w przypadku zbiorników klasy konsekwencji CC3 siły przekrojowe wyznacza się uznanymi metodami komputerowymi, np. metodą elementów skończonych.

Zbiorniki klasy konsekwencji CC2, które charakteryzują się osiową symetrią oddziaływań i podparcia, można obliczać albo wykorzystując analizę numeryczną MES, albo alternatywnie stosując teorię błonową do wyznaczenia naprężeń podstawowych oraz teorię zgięciową powłok sprężystych do opisu lokalnych efektów zginania. Gdy obciążenie zbiornika nie jest osiowo symetryczne, to obliczenia prowadzi się metodą numeryczną.

W przypadku zbiorników klasy konsekwencji CC1 do wyznaczenia naprężeń podstawowych można stosować teorię błonową oraz współczynniki i formuły uproszczone uwzględniające efekty lokalnego zginania i oddziaływania niesymetryczne.

Metody analizy statycznej powłok stalowych zbiorników zalecane do obliczeń wg eurokodu PN-EN 19931-6:2007 [11] przytoczono $w$ tablicy V.
Najprostsza analiza statyczna powłoki wg teorii membranowej $M$ prowadzi do następującego rozwiązania wyrażonego w naprężeniach zastępczych:

$$
\sigma_{\theta q E d}=\frac{1}{t} \sqrt{n_{x E d}^{2}+n_{\theta E d}^{2}-n_{x E d} n_{\theta E d}+3 n_{x \theta E d}^{2}}
$$

Przyjęte we wzorze (7) oznaczenia sił przekrojowych są zgodne z przyjętymi oznaczeniami osi współrzędnych wg normy [1]. Analiza liniowo sprężysta LA lub sprężysta i geometrycznie nieliniowa GNA prowadzi do następującego wzoru na naprężenia zastępcze:

$$
\sigma_{\theta \Phi \notin d}=\sqrt{\sigma_{x E d}^{2}+\sigma_{\theta E d}^{2}-\sigma_{x E d} \sigma_{\theta E d}+3 \tau_{x \theta E d}^{2}}
$$

We wzorze (8) przyjęto oznaczenia:

$$
\begin{gathered}
\sigma_{\mathrm{x} E d}=\left(\frac{n_{x E d}}{t} \pm \frac{4 m_{x E d}}{t^{2}}\right), \sigma_{\theta E d}=\left(\frac{n_{\theta E d}}{t} \pm \frac{4 m_{\theta E d}}{t^{2}}\right) \\
\tau_{x \theta E d}=\left(\frac{n_{x \in E d}}{t} \pm \frac{4 m_{x \oplus E d}}{t^{2}}\right)
\end{gathered}
$$

gdzie: $t$ - grubość powłoki zbiornika, inne symbole wg PN-EN 19934-2 [1].

Zaawansowana analiza statyczna geometrycznie i fizykalnie nieliniowa powłok idealnych lub z imperfekcjami (por. tabl. V) jest prowadzona metodami numerycznymi. Opis matematyczny tego typu zadań przyjmuje postać równań przyrostowych MES, liniowych względem uogólnionych przemieszczeń. Rozwiązanie tych równań wymaga wykorzystania profesjonalnych programów komputerowych.

Tablica V. Rodzaje analizy statycznej powłok zbiorników stalowych wg [11]

Table V. Types of static analysis of steel tank shells acc. to [11]

\begin{tabular}{|c|c|c|c|}
\hline Typ analizy & $\begin{array}{c}\text { Teoria } \\
\text { powłok }\end{array}$ & $\begin{array}{c}\text { Model } \\
\text { materiału }\end{array}$ & $\begin{array}{c}\text { Geometria } \\
\text { powłoki }\end{array}$ \\
\hline Membranowa $M$ & błonowa & $\begin{array}{c}\text { nie ma } \\
\text { zastosowania }\end{array}$ & idealna \\
\hline $\begin{array}{c}\text { Liniowo sprężysta LA } \\
\text { bifurkacyjna LBA }\end{array}$ & liniowa & liniowy & idealna \\
\hline $\begin{array}{c}\text { Sprężysta, geometrycz- } \\
\text { nie nieliniowa GNA }\end{array}$ & $\begin{array}{c}\text { nielinio- } \\
\text { wa }\end{array}$ & liniowy & idealna \\
\hline $\begin{array}{c}\text { Fizykalnie nieliniowa } \\
\text { MNA }\end{array}$ & liniowa & nieliniowy & idealna \\
\hline $\begin{array}{c}\text { Geometrycznie i fizykal- } \\
\text { nie nieliniowa GMNA }\end{array}$ & $\begin{array}{c}\text { nielinio- } \\
\text { wa }\end{array}$ & nieliniowy & idealna \\
\hline $\begin{array}{c}\text { Geometrycznie nielinio- } \\
\text { wa, sprężysta z imper- } \\
\text { fekcjami GNIA }\end{array}$ & $\begin{array}{c}\text { nielinio- } \\
\text { wa }\end{array}$ & liniowy & z imperfek- \\
cjami
\end{tabular}


Powłokę zbiornika sprawdza się ze względu na stany graniczne z uwzględnieniem: zniszczenia plastycznego (LS1), zmęczenia niskocyklowego - nieprzystosowanie plastyczne (LS2), wyboczenia (LS3), zmęczenia (LS4) i stateczności ogólnej. Podstawowe kryterium nośności w stanie zniszczenia plastycznego materiału rodzimego powłoki (LS1) ma postać:

$$
\sigma_{\Theta \notin \notin d} \leq \frac{\boldsymbol{f}_{\boldsymbol{y} k}}{\gamma_{M 0}}
$$

gdzie $f_{y k}$ - wytrzymałość charakterystyczna stali użytej na powłokę.

Jeżeli są spełnione odpowiednie wymagania jakości, to można przyjąć, że efektywność wytrzymałościowa złączy powłoki zbiornika na spoiny czołowe z pełnym przetopem wynosi $100 \%$ wytężenia (10). Złącza na spoiny pachwinowe należy sprawdzić metodą kierunkową lub uproszczoną wg normy PN-EN 1993-1-8 [12]. Kryterium nośności spoiny wg drugiej metody ma postać:

$$
F_{w E d} \leq a \frac{f_{u}}{\sqrt{3} \beta_{w} \gamma_{M 5}}
$$

gdzie: $F_{w E d}-$ wartość obliczeniowa siły na jednostkę długości spoiny, $a$ - grubość obliczeniowa spoiny, $f_{u}$ - wytrzymałość charakterystyczna na rozciaganie stali użytej na powłokę, $\beta_{w}=0,8 \div 1,0$ - współczynnik korelacji dla spoin pachwinowych wg normy [12].

Uwzględnianie w sposób jawny imperfekcji geometrycznych w obliczeniach nie jest wymagane, chyba że stosuje się zaawansowaną metodę analizy statycznej GNIA lub GMNIA. Imperfekcje geometryczne podlegają jednak kontroli bez względu na zastosowaną metodę analizy. Szczególne nasilenie imperfekcji geometrycznych obwodowych i południkowych mogą wywoływać złącza spawane.

Nośność na wyboczenie konstrukcji powłokowych jest uzależniona od poziomu imperfekcji geometrycznych, które mogą mieć zróżnicowaną postać. Imperfekcje są związane z odchyłkami kształtu powłoki technicznej od geometrii idealnej, np. dla zamkniętej powłoki walcowej parametrem charakterystycznym jest średnica $d$, zatem podstawową imperfekcja jest owalizacja przekroju. Imperfekcja taka jest wywołana procesem wytwarzania i montażu konstrukcji, a poziom tolerowanych odchyłek jest kontrolowany. Inny rodzaj imperfekcji to brak współosiowości elementów montażowych, który występuje nie tylko w przypadkach skokowej zmiany grubości blach, ale także przy łączeniu blach o tej samej grubości nominalnej. Zaburzenia kształtu powodują także lokalne wybrzuszenia i załomy blach, zwłaszcza w strefach połączeń spawanych. Dla zamkniętej powłoki cylindrycznej miarą imperfekcji przekroju jest stosunek różnicy średnicy maksymalnej $d_{\max }$ i minimalnej $d_{\min }$ do średnicy nominalnej $d_{\text {nom }}$ :

$$
U_{r}=\frac{d_{\max }-d_{\min }}{d_{n o m}}
$$
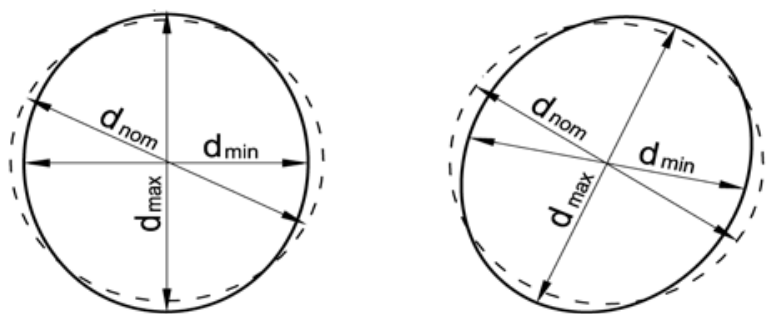

Rys. 1. Deformacje przekroju zamkniętej powłoki cylindrycznej: symetryczne spłaszczenie lub niesymetryczna owalizacja

Fig. 1. Intersection distortion of closed cylindrical shell with symmetrical or non-symmetrical ovalization

Wzór (12) umożliwia ilościową ocenę deformacji przekroju w postaci symetrycznej lub niesymetrycznej (rys. 1). Dopuszczalne wartości parametru $U_{r}$, które definiują trzy klasy imperfekcji powłok stalowych wg zaleceń PN-EN 1993-1-6, zestawiono w tablicy VI.

Przykłady braku współosiowości połączeń paneli pokazano na rysunku 2. Miarą imperfekcji dla blach o stałej grubości jest przesunięcie osi $e_{a}$, a dla blach o zmiennej grubości - bezwymiarowy parametr $U_{e}$, czyli stosunek:

$$
U_{\theta}=\frac{e_{a}}{t_{\text {ave }}}=\frac{e_{\text {tot }}-e_{i n t}}{0,5\left(t_{\min }+t_{\max }\right)}
$$

Graniczne wartości parametru $U_{e}$ oraz mimośrodu $e_{a}$ dla trzech klas imperfekcji powłok stalowych wg zaleceń PN-EN 1993-1-6 zestawiono w tablicy VII.

Tablica VI. Dopuszczalne wartości parametru imperfekcji $U_{r}$

Table VI. Allowable values of imperfection parameter $U_{r}$

\begin{tabular}{|c|c|c|c|}
\hline \multirow{2}{*}{$\begin{array}{c}\text { Klasa } \\
\text { imperfekcji }\end{array}$} & \multicolumn{3}{|c|}{ Średnica nominalna } \\
\cline { 2 - 4 } & $d<0,5 m$ & $0,5 \mathrm{~m}<\mathrm{d}<1,25 \mathrm{~m}$ & $\mathrm{~d} \geq 1,25 \mathrm{~m}$ \\
\hline C & 0,030 & $0,015+0,0200(1,25-\mathrm{d})$ & 0,015 \\
\hline B & 0,020 & $0,010+0,0133(1,25-\mathrm{d})$ & 0,010 \\
\hline A & 0,014 & $0,007+0,0093(1,25-\mathrm{d})$ & 0,007 \\
\hline
\end{tabular}
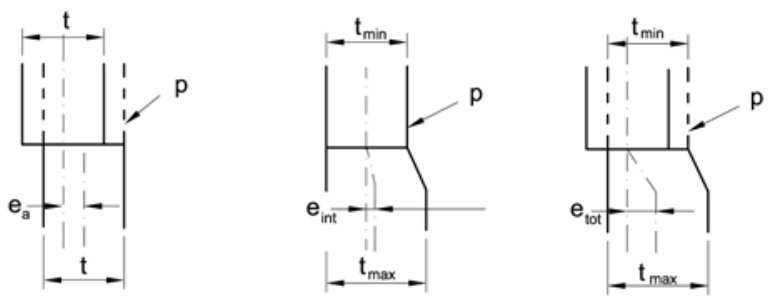

Rys. 2. Brak współosiowości paneli blach

Fig. 2. Lack of coaxiality of plate panels

Tablica VII. Dopuszczalne wartości parametru imperfekcji $U_{e}$ i mimośrodu e

Table VII. Allowable values of imperfection $U_{e}$ and eccentric $e_{a}$ parameter

\begin{tabular}{|c|c|c|}
\hline Klasa imperfekcji & Max $U_{e}$ & Max $\mathrm{e}_{\mathrm{a}}, m m$ \\
\hline C & 0,30 & 4 \\
\hline B & 0,20 & 3 \\
\hline A & 0,14 & 2 \\
\hline
\end{tabular}



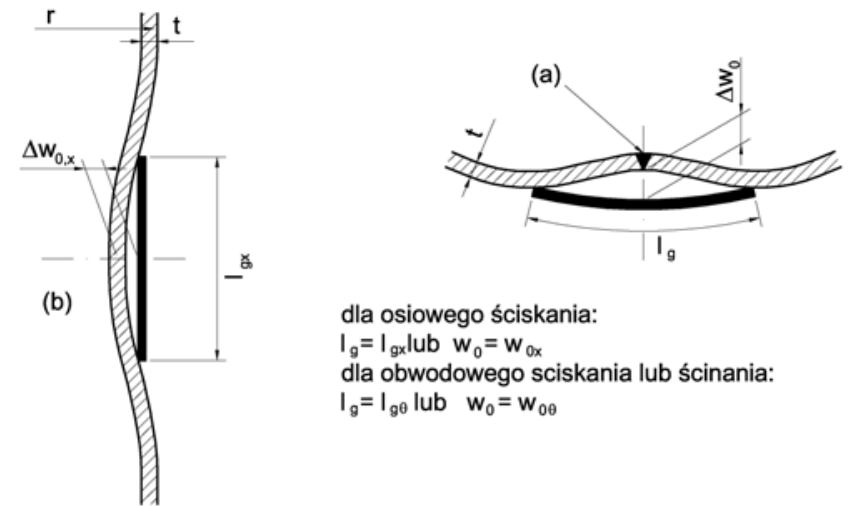

dla osiowego ściskania:

$I_{g}=I_{g x}$ lub $w_{0}=w_{0 x}$

dla obwodowego sciskania lub ścinania: $I_{g}=I_{g \theta}$ lub $W_{0}=W_{0 \theta}$

Rys. 3. Pomiary strzałki wybrzuszeń powłoki walcowej wzdłuż tworzącej i po obwodzie

Fig. 3. Deflection measurements of cylindrical shell along generating line and circumference

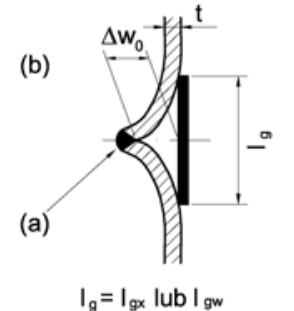

$\Delta \mathrm{w}_{0}=\Delta \mathrm{w}_{0 \mathrm{x}}$ lub $\Delta \mathrm{w}_{0 \mathrm{w}}$

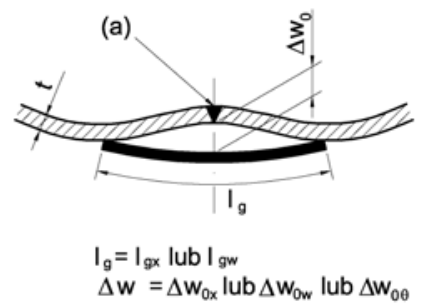

Rys. 4. Pomiary deformacji spawalniczych powłok

Fig. 4. Measurement of welded shells deformation

Tablica VIII. Długość bazy pomiarowej wg PN-EN 1993-1-6 Table VIII. Reference line length acc. to PN-EN 1993-1-6

\begin{tabular}{|c|c|c|}
\hline $\begin{array}{l}\text { Obciążenie } \\
\text { powłoki }\end{array}$ & Kierunek pomiaru & $\begin{array}{l}\text { Długość bazy } \\
\text { pomiarowej }\end{array}$ \\
\hline $\begin{array}{l}\text { Osiowe } \\
\text { ściskanie }\end{array}$ & $\begin{array}{l}\text { południkowy lub } \\
\text { obwodowy przez spoinę }\end{array}$ & $I_{g x}=4 \sqrt{r t}$ \\
\hline $\begin{array}{l}\text { Obwodowe } \\
\text { ściskanie } \\
\text { lub ścinanie }\end{array}$ & obwodowy & 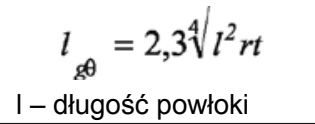 \\
\hline $\begin{array}{l}\text { Dowolne } \\
\text { ściskanie }\end{array}$ & $\begin{array}{l}\text { przez spoinę oba } \\
\text { kierunki południkowy } \\
\text { i obwodowy }\end{array}$ & $\begin{array}{l}\mathrm{I}_{\mathrm{gw}}=25 \mathrm{t} \text { lub } \mathrm{I}_{\mathrm{gw}}=25 \mathrm{t}_{\min } \\
\text { oraz } \mathrm{I}_{\mathrm{gw}} \leq 500 \mathrm{~mm} \\
\mathrm{t}_{\text {min }}-\text { mniejsza z grubości } \\
\text { spawanych blach }\end{array}$ \\
\hline
\end{tabular}

Wybrzuszenia wykonawcze powłok walcowych pokazano na rysunkach 3 i 4 . Miarą deformacji powłoki jest strzałka wybrzuszenia $\Delta \mathrm{w}_{\mathrm{o}}$, jaką można zmierzyć na bazie liniowej lub łukowej I. Zalecane wymiary bazy pomiarowej wg PN-EN 1993-1-6 zestawiono w tablicy VIII. Bezwymiarowy parametr imperfekcji powierzchniowej ma postać:

$$
U_{o i}=\frac{\Delta_{w i}}{l_{a g i}} \quad i=x, \theta, w .
$$

Dopuszczalne wartości parametru imperfekcji

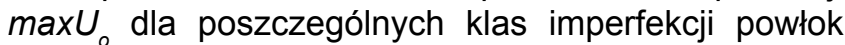
wg normy PN-EN 1993-1-6 wynoszą:

- dla klasy $C \max U_{0}=0,016$

- dla klasy $B \max U_{0}=0,010$

- dla klasy $A \max U_{o}^{\circ}=0,006$

\section{Przykład obliczeń zbiornika stokażowego}

Sprawdzić warunki nośności powłoki stalowego naziemnego zbiornika walcowego o osi pionowej, z dachem stożkowym stałym, dla następujących danych i warunków:

- Przeznaczenie - zbiornik wody amoniakalnej: $q=898 \mathrm{~kg} / \mathrm{m}^{3}$ (klasa konsekwencji CC3).

- Temperatura obliczeniowa płaszcza $t=100^{\circ} \mathrm{C}$.

- Nadciśnienie w przestrzeni powietrznej $p_{n}=5,0 \mathrm{kPa}$ lub podciśnienie $\mathrm{p}_{\mathrm{p}}=-0,5 \mathrm{kPa}$.

- Gatunek stali 1.4301 (X5CrNi18-10) (naddatek grubości blach na korozję $0,5 \mathrm{~mm}$ ).

- Ocieplenie pobocznicy i dachu - wełna mineralna $8 \mathrm{~cm}+$ bl. Al $1 \mathrm{~mm}$.

- Obciążenia użytkowe pomostu technologicznego $\mathrm{q}=1,5 \mathrm{kN} / \mathrm{m}^{2}$

- Lokalizacja - Puławy.

Schemat zbiornika i jego podstawowe wymiary pokazano na rysunku $5 a$, a szczegóły konstrukcji połączenia pobocznicy $z$ dnem i dachem na rysunku $5 b$. Połączenia spawane spoinami warsztatowymi i montażowymi należy wykonać, uwzględniając klasę wykonania konstrukcji EXC $3 \mathrm{wg}$ klasyfikacji normy PN-EN 1090-2 (pełna kontrola jakości złączy spawanych).

Konstrukcję powłokową zbiornika zaprojektowano jednolicie $z$ blach o grubości $t=6 \mathrm{~mm}$ połączonych spoinami czołowymi (połączenie pobocznicy $z$ dachem i dnem jak na rysunku 5b), ze stali 1.4301 (X5CrNi18-10 - stal austenityczna w stanie przesyconym), dla której wytrzymałość charakterystyczna wg PN-EN 10028-7:2004 [2] wynosi:

- w temperaturze $20^{\circ} \mathrm{C}$ (warunek próby wodnej) $f_{y k}=210 \mathrm{MPa}$ i $f_{u}=520 \mathrm{MPa}$,

- $w$ temperaturze eksploatacyjnej $100^{\circ} \mathrm{C}: f_{y k}=157$ $\mathrm{MPa}$ i $f_{u}=460 \mathrm{MPa}$.

a)
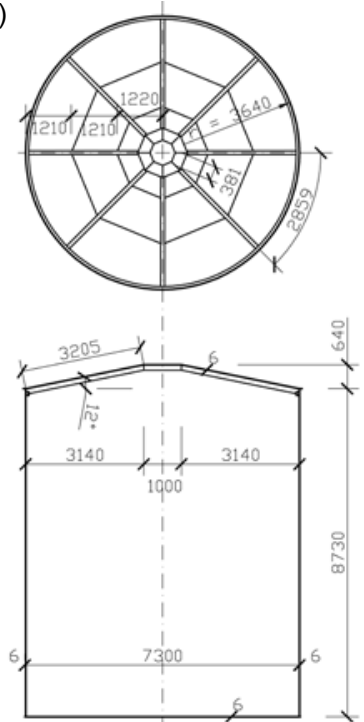

Rys. 5. Zbiornik na wodę amoniakalną: a) schemat zbiornika, b) szczegóły konstrukcji

Fig. 5. Ammonia water steel tank: a) the scheme of tank, b) details of structure b)

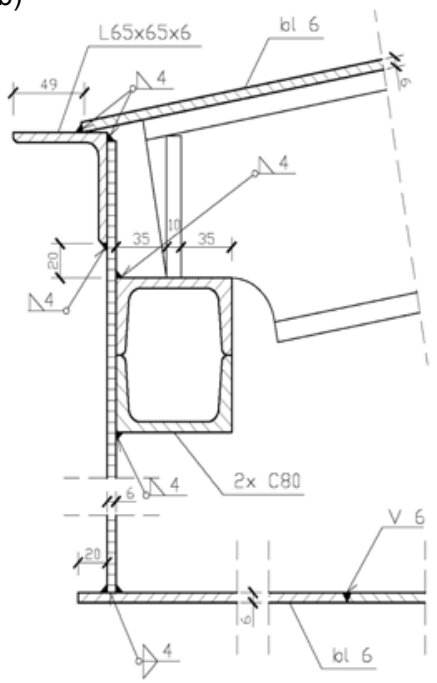


Przyjęto następujące wartości współczynników częściowych:

- dla oddziaływań: $\gamma_{F}=1,40$ dla parcia wody amoniakalnej, $\gamma_{F}=1,50$ dla pozostałych obciążeń zmiennych oraz $\gamma_{F}=1,35(1,00)$ dla obciążeń stałych,

- współczynniki nośności $\gamma_{M O}=1,10$ (uwzględniono pośrednio wyniki weryfikacji statystycznej wg tabl. III oraz $\gamma_{M 2}=\gamma_{M 5}=1,25$.

Uwzględniając klasę konsekwencji CC3, której odpowiada klasa niezawodności RC3, przyjęto współczynniki redukcyjne wg tablicy IV: dla obciążeń $K_{F i}=1,1$ oraz dla nośności plastycznej blach $K_{R}=1,05$.

Uwzględniając powyższe warunki wyjściowe i założenia opracowano model komputerowy zbiornika, z uwzględnieniem szczegółów konstrukcyjnych pokazanych na rysunku 5b. Otrzymane wyniki obliczeń numerycznych, wymiarujące blachę powłoki zbiornika (dla schematu obciążeń: nadciśnienie + działanie wiatru + parcie wody amoniakalnej + minimalny ciężar własny) pokazano na rysunku 6 - pobocznica i dach oraz na rysunku 7 - dno zbiornika. Z wyskalowanej na
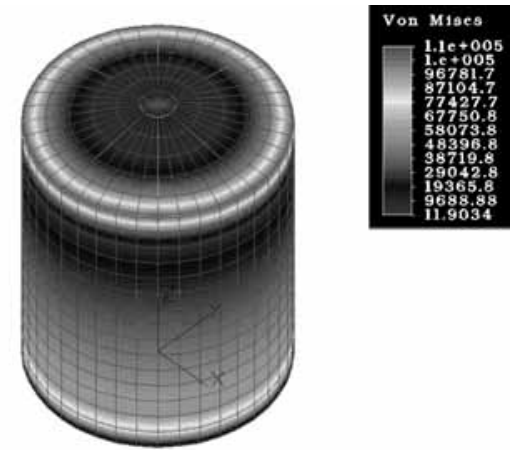

Rys. 6. Mapa naprężeń zastępczych $\sigma_{e q E d}$ pobocznicy i dachu zbiornika, kPa

Fig. 6. Substitute stress distribution $\sigma_{\text {eqEd }}$ in side surface and tank roof, $\mathrm{kPa}$

\section{Podsumowanie}

System współczynników częściowych wprowadzony do metody stanów granicznych wg eurokodu EN 1990 to nowy problem badawczy, ponieważ dotyczy dotąd niestosowanej formacji wymiarowania konstrukcji budowlanych w Polsce. Współczynniki nośności $\gamma_{M}$, stosowane do oceny niezawodności zbiorników stalowych na ciecze i gazy płynne, zostały podane w eurokodzie EN 1993-4-2, z zastrzeżeniem o możliwej odmiennej specyfikacji regionalnej. Załącznik krajowy do eurokodu PN-EN 1993-4-2 takiej specyfikacji nie podaje, zalecając jednocześnie - bez weryfikacji statystycznej wytrzymałości wyrobów hutniczych produkowanych w Polsce (współczynniki $\gamma_{M 0}$, $\gamma_{M 2}, \gamma_{M 5}$ ) specyfikacje z normy EN 1993-4-2. Przeprowadzona kontrolna weryfikacja współczynników: nośności plastycznej blach (współczynnik $\gamma_{M 0}$ ), nośności blach stalowych na rozerwanie (współczynnik $\gamma_{M 2}$ ) oraz nośności złączy spawanych (współczynnik $\gamma_{M 5}$ ) wykazała, że specyfikacje europejskie w odniesieniu rysunku 6 mapy naprężeń zastępczych wynika miarodajne kryterium niezawodności powłoki zbiornika:

$$
\begin{gathered}
K_{F i} \sigma_{\text {eqEd }} 1,1 \cdot 113,7=125 \mathrm{MPa} \leq \frac{f_{y k}}{K_{\boldsymbol{R}} \gamma_{M 0}}= \\
=\frac{157}{1,05 \cdot 1,1}=136 \mathrm{MPa} .
\end{gathered}
$$

W warunku (15) mnożnik $K_{F i}$ należy stosować tylko do obciążeń zmiennych, jednak wpływ obciążeń stałych na wytężenia powłoki zbiornika jest znikomy, dlatego dla ujawnienia pozycji elementów niezawodności konstrukcji powłoki zastosowano zapis jak wyżej. Inne warunki stanu granicznego nośności powłoki albo nie są miarodajne (LS2 i LS4), albo są konstrukcyjnie spełnione (LS3 - zgodnie z kryterium z PN-EN 1993-4-2 dla zachowania stateczności nie potrzeba pierścienia pośredniego usztywniającego pobocznicę zbiornika).
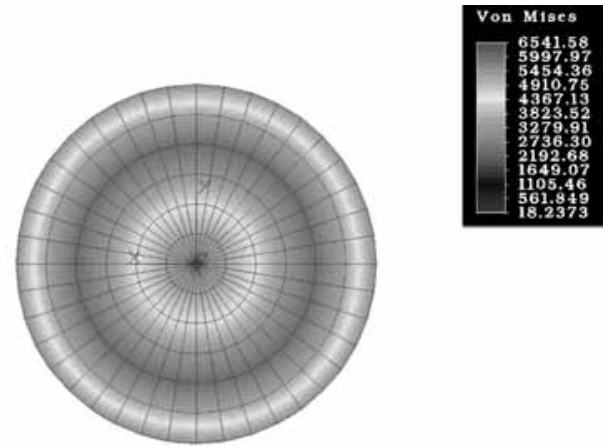

Rys. 7. Mapa naprężeń zastępczych $\sigma_{\text {eqEd }}$ dna zbiornika, kPa Fig. 7. Substitute stress distribution $\sigma_{e q E d}$ in tank bottom, $\mathrm{kPa}$

do jakości wyrobów krajowych na ogół nie są uzasadnione. Do weryfikacji wykorzystano reprezentatywną próbę statystyczną wytrzymałości blach zestawioną w latach 1963-1968 przez Z. Menderę [9]. W szczególności wg tych danych, empiryczna obliczeniowa granica plastyczności badanych blach jest mniejsza od wartości nominalnej, co oznacza, że wartości współczynnika nośności plastycznej $\gamma_{M 0}>1,0$ (tabl. III). Weryfikacja statystyczna dała pozytywny wynik w przypadku wytrzymałości blach na rozciąganie, która charakteryzuje nośność złączy spawanych (współczynnik $\gamma_{M 2}=\gamma_{M 5}$ ).

Z uwagi na zmiany systemowe, jakie zaszły w Polsce w latach 1990., w świetle otrzymanych w pracy rezultatów, konieczne jest ponowne zestawienie próby statystycznej wytrzymałości współcześnie produkowanych krajowych wyrobów hutniczych i weryfikacja statystyczna współczynników materiałowych. 


\section{Literatura}

[1] PN-EN 1993-4-2:2009. Eurokod 3. Projektowanie konstrukcji stalowych. Część 4-2: Zbiorniki.

[2] PN-EN 10028-7:2004. Wyroby płaskie ze stali na urządzenia ciśnieniowe. Część 7: Stale odporne na korozję.

[3] PN-EN 14015:2010. Zarządzanie środowiskowe - ocena środowiskowa miejsc i organizacji (EASO).

[4] PN-EN 14620:2010. Projektowanie i budowa na miejscu użytkowania pionowych, walcowych zbiorników stalowych o płaskim dnie, do magazynowania oziębionych, skroplonych gazów o temperaturach roboczych pomiędzy $0^{\circ} \mathrm{C} \mathrm{i}-165^{\circ} \mathrm{C}$.

[5] PN-EN 1090-2:2009. Wykonanie konstrukcji stalowych i aluminiowych - Część 2: Wymagania techniczne dotyczące wykonania konstrukcji stalowych.

[6] Rozporządzenie Ministra Gospodarki z dnia 16 kwietnia $2002 \mathrm{w} / \mathrm{s}$ warunków technicznych dozoru technicznego, jakim powinny odpowiadać zbiorniki bezciśnieniowe i niskociśnieniowe przeznaczone do magazynowania materiałów trujących lub żrących. Dz.U. nr 63, poz. 572.
[7] PN-EN 1990:2004. Eurokod. Podstawy projektowania konstrukcji.

[8] Gwóźdź M., Machowski A.: Wybrane badania i obliczenia konstrukcji budowlanych metodami probabilistycznymi. Wydawnictwo Politechniki Krakowskiej. Kraków 2011 (w dru$\mathrm{ku})$.

[9] Mendera Z.: Zagadnienia stanów granicznych konstrukcji stalowych. Wydawnictwa Politechniki Krakowskiej, Budownictwo Lądowe z. 33, Zeszyt Naukowy 7, Kraków 1967.

[10] Murzewski J.: Niezawodność konstrukcji Inżynierskich. Arkady, Warszawa 1989

[11] PN-EN 1993-1-6:2007. Eurokod 3. Projektowanie konstrukcji stalowych. Część 1-6: Wytrzymałość i stateczność konstrukcji powłokowych.

[12] PN-EN 1993-1-8: 2005. Projektowanie konstrukcji stalowych. Część 1-8: Projektowanie węzłów.

\section{Wydarzenia}

\section{Nowy standard z rodziną urządzeń Kempact RA}

Fiński producent urządzeń spawalniczych Kemppi Oy wprowadził na rynek nową linię kompaktowych urządzeń MIG/MAG, ustanawiając tym samym nowe standardy we wzornictwie przemysłowym i charakterystyce produktu.

Urządzenia z rodziny Kempact RA powstały z myślą o potrzebach nowoczesnych warsztatów spawalniczych. Charakteryzują się unikalnym, eleganckim, a zarazem praktycznym wzornictwem. Zostały skonstruowane z wykorzystaniem nowoczesnych rozwiązań i z myślą o spełnianiu potrzeb klienta, a wszystko po to, żeby spawanie było wydajne, precyzyjne i efektywne. Ich konstrukcja powstała na bazie najnowszych rozwiązań Kemppi w zakresie budowy źródeł spawalniczych, dzięki czemu oferują wysoką jakość spawania i maksymalne wykorzystanie energii. Do wyboru jest 11 modeli o maksymalnym prądzie spawania 180,250 i 320 A. Istnieje również możliwość wyboru pomiędzy wersją sterowaną ręcznie $(R)$ i adaptacyjnie (A). Dzięki różnorodnym modelom maszyna ta zaspokaja szeroki wachlarz potrzeb zakładów zajmujących się obróbką metali. W zestawie znajduje się uchwyt spawalniczy i kabel masy.

Dzięki zaawansowanej technologii udało się zredukować koszty energii o $10 \%$ w porównaniu do konwencjonalnych, skokowo regulowanych źródeł spawalniczych. Maszyna ma też wiele innowacyjnych rozwiązań: oświetlenie komory szpuli Brights ${ }^{\mathrm{TM}}$, ułatwiające wymianę drutu w miejscach słabo oświetlonych, wskaźnik serwisu WireLineTM sygnalizujący potrzebę przeglądu układu podającego drut oraz zintegrowane podwozie GasMate ${ }^{\mathrm{TM}}$, ułatwiające montaż butli z gazem i przemieszczanie maszyny przy jednocześnie zwiększonym bezpieczeństwie personelu. Niezależnie od wybranego modelu, urządzenie Kempact RA zapewnia wykonanie każdego zadania spawalniczego z najwyższą jakością. Urządzenie Kempact RA powstało z myślą o przyszłym użytkowniku. Wszystko, od czytelnego i łatwego w obsłudze panelu sterowania LCD, umieszczonego na optymalnej wysokości, poprzez innowacyjną konstrukcję podwozia, wbudowane szufladki na części zapasowe i oświetlenie komory szpuli za pomoca diod LED, sprawia, że praca z maszyną Kempact RA to przyjemność. Modele ze sterowaniem ręcznym (oznaczenie $R$ ) umożliwiają ręczną regulację napięcia i prędkości podawania drutu. Są wyposażone w bogatą gamę funkcji standardowych, w tym wybór

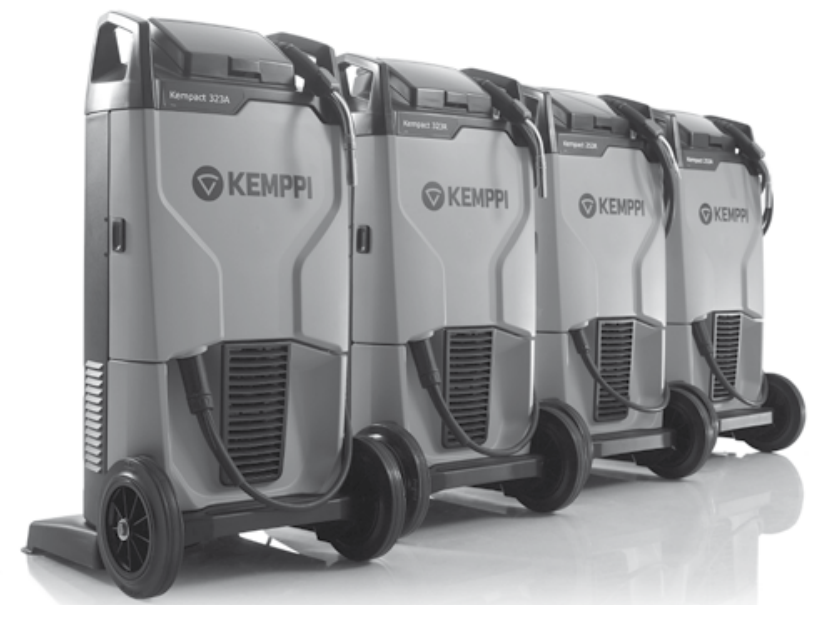

rodzaju gazu, przełącznik 2T/4T, funkcje SPOT/CYCLE ARC i HOT SPOT, specjalistyczną funkcję punktowego podgrzewania blachy przeznaczoną dla profesjonalnych blacharzy i warsztatów samochodowych. Modele sterowane adaptacyjnie (oznaczenie A) mają wszystkie funkcje standardowe, a także kanały pamięci i tryb adaptacyjnej regulacji parametrów spawania, w którym moc spawania automatycznie dopasowuje się do zadanej grubości spawanego materiału.

Doceniana za innowacyjną i praktyczną konstrukcję rodzina urządzeń Kempact RA została niedawno nagrodzona uznaną, międzynarodową nagroda iF 2012 w kategorii wzornictwa przemysłowego. Organizowany w Niemczech konkurs iF jest jednym z najstarszych i najbardziej znanych na świecie. Konkurs jest organizowany przez iF Forum Design e.V., które każdego roku powołuje międzynarodowe jury złożone z ekspertów w dziedzinie wzornictwa, które testuje i ocenia zgłoszone produkty. Nagroda iF od ponad 60 lat jest uznawana na całym świecie za dowód doskonałego wzornictwa. 